\title{
破断試験による大型鉛プラグ入り積層ゴムの終局特性評価 ULTIMATE PROPERTIES OF LARGE-SCALE LEAD RUBBER BEARING USING FULL-SCALE BREAK TEST
}

\author{
小杉慎 司 $^{* 1}$, 今岡哲男 ${ }^{* 2}$, 金澤健司*3, 平木隆文*4, 永田聖二*5, \\ 中山尚之*6, 佐藤邦彦*7, 神 保雅一 ${ }^{* 8}$, 梅木芳人*9 \\ Shinji KOSUGI, Tetsuo IMAOKA, Kenji KANAZAWA, \\ Takafumi HIRAKI, Seiji NAGATA, Takashi NAKAYAMA, \\ Kunihiko SATO, Masakazu JIMBO and Yoshito UMEKI
}

\begin{abstract}
Application of a seismic base-isolation system using lead rubber bearings (LRBs) has been developed for the purpose of enhancing the seismic safety of nuclear power plants (NPPs). To grasp the mechanical properties of the seismic isolator over the design limit, the break tests for a 1600-mm diameter LRB have been conducted using full-scale specimens in order to avoid the difficulties considering size effect. As a result, linearity limit state and break limit state of the full-scale LRBs were found to be well-evaluated as expected; i.e., the breaking shear strain under axial compression shall exceed the commercial reference value of $400 \%$. Further, statistical models of linearity limit and break limit of LRBs are evaluated on the basis of the real-sized break tests. By using these statistical models of limit state of the LRBs, a residual risk for seismic base-isolated NPPs against earthquake events beyond design basis can be investigated more accurately.
\end{abstract}

Keywords: Seismic isolation, Lead rubber bearing, Ultimate property, Breakage, Full-scale test 免震，鉛プラグ入り積層ゴム，終局特性，破断，実大実験

\section{1.はじめに}

免震構造では地震時の応答を長周期化し減衰させることで構造物 に作用する地震力の低減が可能となる。この免震構造を原子力発電 所施設へ適用することで建屋および建屋内に設置された機器類の耐 震安全性の向上，或いはプラント設計標準化が期待できる。このた め, 原子力発電所施設を対象とした建屋水平免震構造の研究開発 5) が活発に行われており，免震構造に係る民間規格 ${ }^{6}$ )が既に整備され ている。その一方で, 2006 年に改訂された耐震設計審查指針 7)では, 設計想定を超える地震動の生起およびそれに起因する施設の損傷や 放射性物質拡散の可能性が残余のリスクとして明記されており，そ の評価が要求さるようになった。しかしながら, 国内では免震構造 が適用された原子力発電施設がないため, 免震構造を対象とした残 余のリスクの評価方法は未だ確立されていない。以上の背景の下で, 2009 年から「原子力施設の免震技術の開発」と題して, (1)免震建屋
挙動評価手法の開発，(2)免震要素の力学特性把握，(3)残余のリスク 評価の手法確立を目的とした研究開発が経済産業省補助事業「発電 用原子炉等安全対策高度化技術開発」の一環として電力共同研究で 実施された 8),9)。本論文は(2)に関して, 軽水炉型原子炉建屋の免震 装置として試設計されたゴム径 $1600 \mathrm{~mm}$ （以下， $\phi 1600$ と称す） の鉛プラグ入り積層ゴムを対象とした破断試験について報告する。

原子力施設を対象とした積層ゴムの設計では，水平方向もしくは 軸引張方向の荷重履歴曲線において剛性が急変寸る変位あるいは応 力を線形限界（せん断ひずみ $250 \%$ 程度，引張応力 $1.0 \mathrm{MPa}$ 程度） とし，これに安全率を考慮して設計応答レベルが規定されている ${ }^{6)}$ 残余のリスク評価では，線形限界を超える領域における水平方向の ハードニング挙動や軸引張方向のソフトニング挙動，破断といった 積層ゴムの終局挙動の把握が重要となる。積層ゴムの終局特性を得 るための積層ゴム単体の載荷試験や振動台を用いた加振試験がこれ

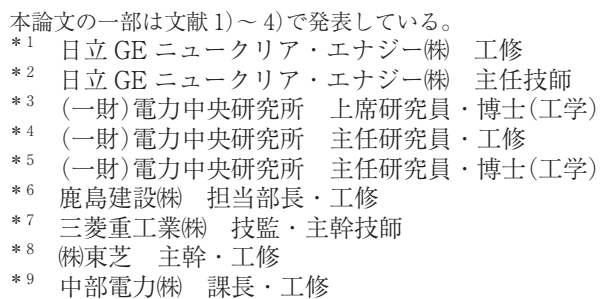

本論文の一部は文献 1)～4)で発表している

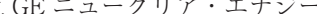

*3 (一財)電力中央研究所 上席研究員 $\cdot$ 博士 $($ 工学

*4 (一財) 電力中央研究所 主任研究員 $\cdot$ 工修

*6 鹿島建設(株) 担当部長. 王修

*7 三菱重工業(株) 技監・主幹技師

$* 9$ 中部電力株) 課長. 工修

Staff Engineer, Hitachi-GE Nuclear Energy, Ltd., M.Eng.

Senior Engineer, Hitachi-GE Nuclear Energy, Ltd.

Senior Research Engineer, Central Research Institute of Electric Power Industry, Dr.Eng.

Research Engineer, Central Research Institute of Electric Power Industry, M.Eng.

Research Engineer, Central Research Institute of Electric Power Industry, Dr.Eng.

Senior Manager, Kajima Corporation, M.Eng.

Deputy Chief Engineer, Mitsubishi Heavy Industries, Ltd.

Chief Specialist, Toshiba Corporation, M.Eng.

Senior Manager, Chubu Electric Power Co., Inc., M.Eng. 
までにも数多く実施されている 5), 10) 16)。既往研究により, 漸増交番 載荷による破断より単調載荷の場合に破断ひずみが小さくなる傾向 があることや 10), 15), 免震構造システムの動的挙動に対する破断限界 が積層ゴム単体の静的載荷試験により評価できること 16)が明らか となっている。しかしながら, 破断試験が実施されているのは $\phi 800$ 以下の積層ゴムが多く, 試験装置の載荷性能の制約によって最大で も $\phi 1200$ の積層ゴムに限られている。松村らによる研究 14)では, 大径の積層ゴムほど引張破断時の軸ひずみが低下寸ることが指摘さ れており，積層ゴムの破断特性に対するスケール効果が無視できな いことから， $\phi 1600$ の積層ゴムについても実大の試験体を用いて破 断特性を評価することが望ましい。また，残余のリスク評価におい ては, 免震構造を含む地震時の建屋応答を確率統計的に評価するこ とになるが，その評価に必要となる積層ゴムの破断限界を個々の積 層ゴムの性能のばらつきを考慮して定めた事例はない。

そこで, $\phi 1600$ の鉛プラグ入り積層ゴム (Lead Rubber Bearing, 以下，LRB と称す）の終局特性を把握することを目的として, 破断 試験装置を新たに設計・製作した上で, 実大試験体を用いた静的単調 載荷による破断試験を実施した。本論文では, 破断試験により得ら れたデータを分析して $\phi 1600 \mathrm{LRB}$ の基本特性や線形限界, 破断特 性を評価する。さらに, 免震構造設計技術指針 17)の考え方を踏襲し て, 残余のリスク評価で参照される免震装置単体の健全性評価にお ける線形限界および破断限界を試験結果に基づいて設定する。

\section{2. 試験概要}

\section{1. 試験体}

試験体として用いた LRB の仕様および外形を Table 1, Fig. 1 に 示寸。この LRB は軽水炉型原子炉建屋向けの免震装置として, 地 震応答解析に基づき設計している ${ }^{18)}$ 。地震応答解析では最大加速度 $800 \mathrm{~cm} / \mathrm{s}^{2}$, 最大応答速度 $200 \mathrm{~cm} / \mathrm{s}$ の水平方向の入力地震動に対して, 免震建屋基礎部で応答加速度 $300 \mathrm{~cm} / \mathrm{s}^{2}$ 以下かつ, 応答変位 $40 \mathrm{~cm}$ 以 下の応答目標, 主要機器の固有周期帯を外すことなどの条件を考慮 して LRB の周期や降伏震度等の仕様を設定した。本研究では, こ の LRB 約 300 基で原子炉建屋を支持する免震システムを想定した。

Table 1 の仕様のうち, ゴム径の $\phi 1600$ は 2010 年の設計時にお いて国内で製造可能な最大径 ${ }^{19}$ であり, これは, 座屈しにくい構造 として二次形状係数 $\mathrm{S}_{2}$ を 5 以上に設定することと, 許容される免震 変位を大きくするためにゴム総厚を大きくすることに配慮した。そ の他の仕様として, ゴム種は $\mathrm{G} 4$ (せん断弾性係数約 $0.4 \mathrm{~N} / \mathrm{mm}^{2}$ ) で, ゴム層は 26 層で総厚 $260 \mathrm{~mm}$ とし, 水平周期は $3.41 \mathrm{~s}$, 支持荷重を $9000 \mathrm{kN}$ とした。一般建築で用いられる積層ゴムと異なる点として, 降伏震度 0.121 を満足するために鉛プラグを太径化し, 鉛プラグ縦 横比は従来設計の下限值 $1.25^{6)}$ を下回る 1.097 とした点が挙げられ る。また，支持面圧は-4.8MPa（引張を正值，圧縮を負值で表す） と設定しており，一般建築の積層ゴムで用いられている-15MPa) よりも低い。

Fig. 1 に示寸試験体は, ゴムと中間鋼板からなる積層ゴム部を Table 1 に示した仕様に合致するように製作し, フランジやボルト 等の固定部を積層ゴム部に先行して破壊しないように強度を上げて 設計した。a)に示す $\phi 1600$ で鉛プラグが中央に 1 本配置されたタイ
Table 1 Design specifications of full-scale LRB

\begin{tabular}{ll}
\hline Rubber diameter & $1,600 \mathrm{~mm}$ \\
Bearing load & $9,000 \mathrm{kN}$ \\
Axial stress & $-4.8 \mathrm{MPa}$ \\
Rubber type & $\mathrm{G} 4$ \\
Horizontal period $\mathrm{T}_{2}$ & $3.41 \mathrm{~s}$ \\
Inner rubber & $10.0 \mathrm{~mm} \times 26$ layers \\
Inner steel plate & $6.8 \mathrm{~mm} \times 25$ layers \\
Primary shape factor $\mathrm{S}_{1}$ & 40.0 \\
Secondary shape factor $\mathrm{S}_{2}$ & 6.2 \\
Vertical frequency & $16.3 \mathrm{~Hz}$ \\
Yield seismic intensity B & 0.121 \\
Lead plug diameter & $392 \mathrm{~mm} \times 1^{* 1}\left(196 \mathrm{~mm} \times 4^{* 2}\right)$ \\
Aspect ratio of lead plug & $1.097^{* 1}\left(2.190^{* 2}\right)$ \\
\hline *1: Full-scale type, Product B type, ${ }^{*} 2:$ Mluti-plug type
\end{tabular}

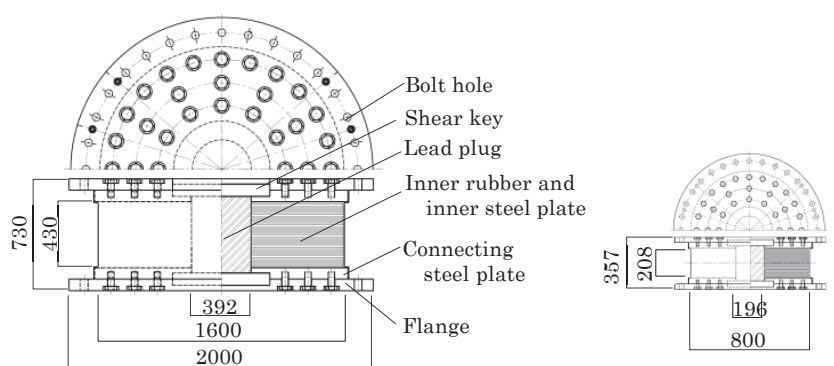

a) Full-scale type $\left(F^{* 1}\right)$

b) Half-scale type $\left(\mathrm{H}^{* 1}\right)$

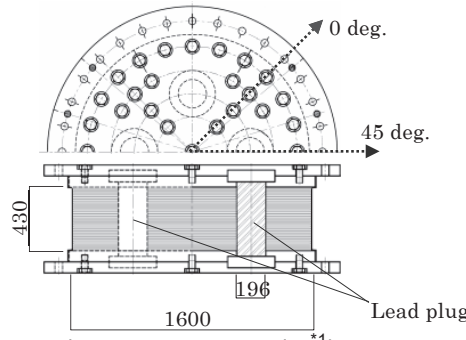

c) Multi-plug type $\left(\mathrm{M}^{* 1}\right)$

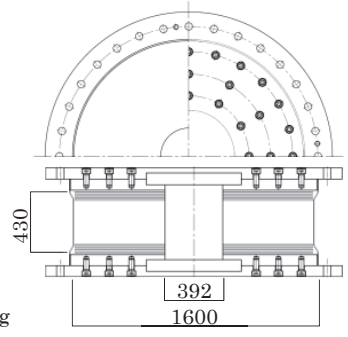

d) Product $B$ type $\left(B^{* 1}\right)$
* 1 :Abbreviation of specimen referred in Fig. 2 Fig. 1 Specimen of lead rubber bearing

プの積層ゴムを実大試験体と称して複数の載荷条件で試験を行った。 b)の縮小試験体は，実大試験体の寸法を $1 / 2$ にした縮小試験体であ り，実大試験体では試験が困難となる高圧縮面圧下での試験に用い た。また，c）のマルチプラグ試験体は，前述の太径鉛プラグ 1 本を 配置する形式に対して鉛プラグを 4 本に分割して配置することで鉛 プラグの縦横比を改善したものである。さらに，d)の製品 B 試験体 は，製造方法による影響を確認するためのもので，実大試験体と同 じ仕様で製造メーカが異なる試験体である。

\section{2. 試験条件}

試験として, LRB の設計レベルの力学特性を取得する基本特性試 験と，線形限界を超えた領域における終局挙動を把握する破断試験 の 2 種類を実施する。基本特性試験では, 設計レベルの振幅におけ る交番載荷を行い, 二次剛性, 降伏荷重特性值, 圧縮剛性といった 基本特性を評価する。一方，破断試験では試験体が破断するまでの 静的単調載荷を行い，線形限界および破断特性を評価する。破断試 験の詳細な内容について以下に述べる。

破断試験の載荷条件を Fig. 2 に示す。破断試験では水平方向及び 鉛直方向の複合的な地震荷重の作用を考慮して，一定面圧下でのせ 几断破断試験と, 水平方向へオフセットさせた状態で軸方向に引っ 張ることで破断に至らしめるオフセット引張破断試験の 2 種類の試 


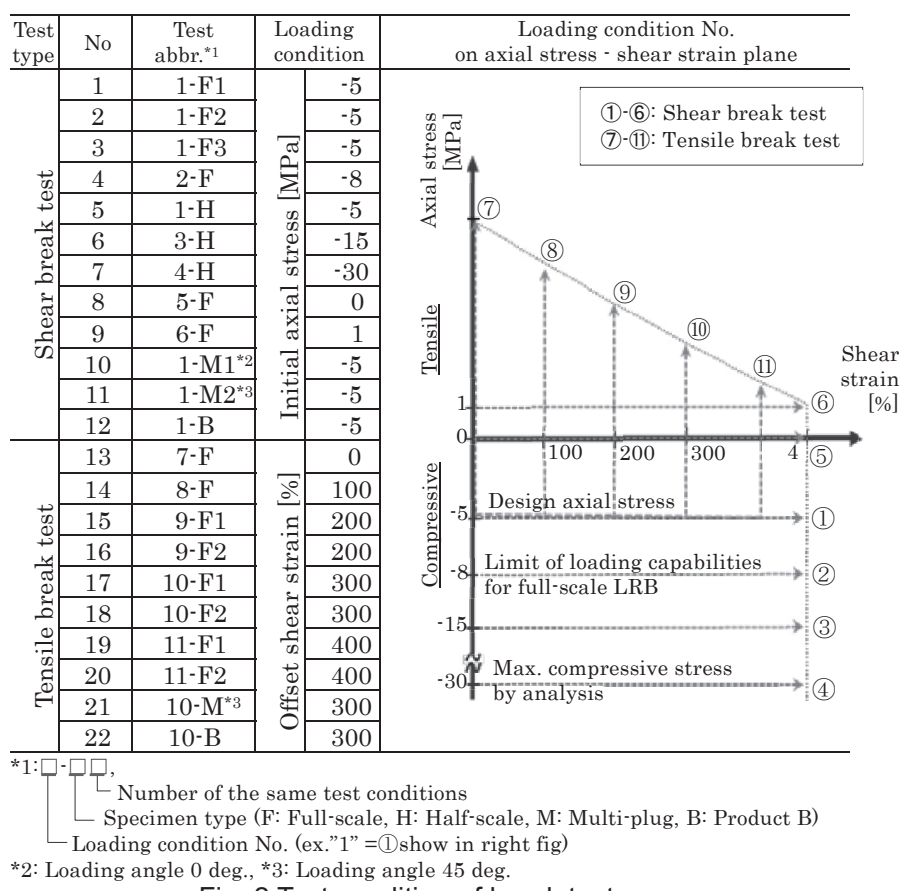

Fig. 2 Test condition of break test

験を行った。まず, 実大試験体について, せん断破断試験を面圧-8, $-5,0,1 \mathrm{MPa}$ の 4 水準,引張破断試験をオフセットせん断ひずみ 0,100 , $200,300,400 \%$ の 5 水準で実施した。特に, 同一載荷条件下における 特性值のばらつきを確認するため, 設計面圧- $4.8 \mathrm{MPa}$ 相当として設 定した基準面圧-5MPa のせん断破断試験で 3 体, オフセット 200,300,400\%の引張破断試験では 2 体づつの試験を実施した。また, 試験装置の性能の制約により実大試験体では面圧-8MPa 以上の圧 縮面圧下の試験が困難なため, 高面圧領域の試験では縮小試験体を 用いた。縮小試験体では, 地震応答解析 18)で得られた LRB 破断時 の最大圧縮面圧である $-30 \mathrm{MPa}$ と, その半分の- $15 \mathrm{MPa}$, および基準 面圧の-5MPa の 3 ケースのせん断破断試験を行った。実大試験体と 縮小試験体で共通寸る試験条件の-5MPa における試験結果の比較 から，試験体スケールによる影響を確認した。

マルチプラグ試験体および製品 B 試験体については，せん断破断 試験と引張破断試験の代表的な載荷条件を 1 ケースずつ実施した。 せん断破断試験として基準面圧-5MPa を選定した。引張破断試験で は, 地震応答解析 18)により, 引張面圧は鉛直地震動とロッキング応 答の重畳により生起するため, ロッキング応答が増大寸るオフセッ 卜量が大きい領域における応答が評価上重要となることが確認され たこと, 仮にオフセット $400 \%$ とした場合, オフセット設定時にせ 儿断破断する恐れがあることの 2 点を考慮して，オフセット $300 \%$ を選定した。さらに, マルチプラグ試験体では, 平面内の鉛プラグ 配置の異方性を考慮して, Fig. 1 の) に示した $0^{\circ}$ 配置と $45^{\circ}$ 配置の 2 ケースについてせん断破断試験を行い, 方向性の影響を検討した。 オフセット $300 \%$ での引張破断試験は, 破断時のせん断ひずみが大 きい結果となった 45 配置に対して行った。

\section{3. 試験装置および計測項目}

破断試験に用いた試験装置の外形を Fig. 3, 仕様を Table 2, 試 験体近傍の計測図を Fig. 4 に示す。この試験装置は $\phi 2000$ までの

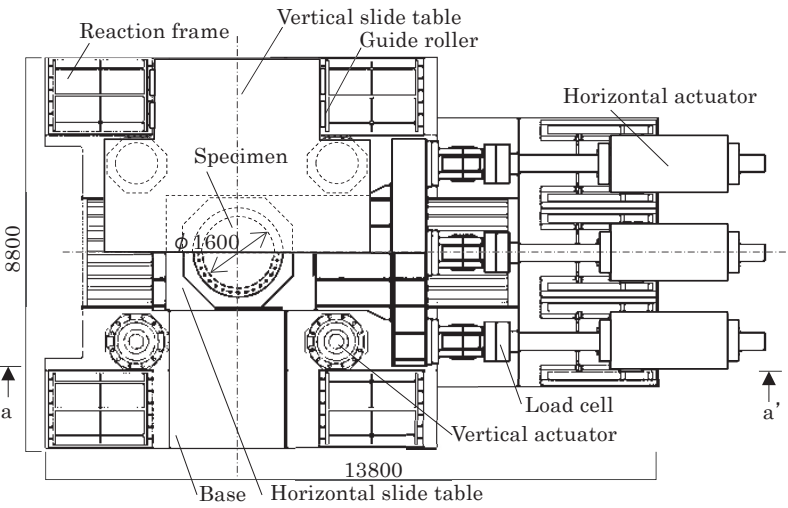

a) Plane view (Upper b-b', Lower c-c' in Fig.b) )

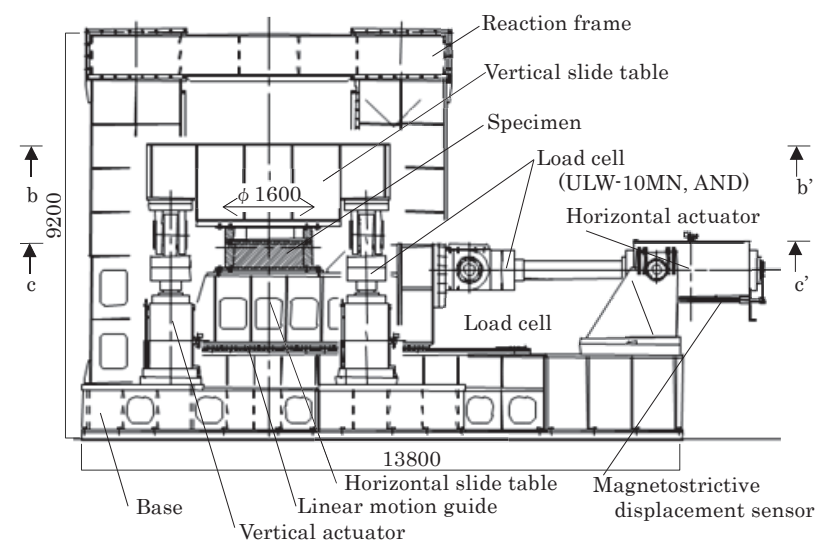

b) Elevation view(a-a' in Fig.a))

Fig. 3 Break test facility for full-scale seismic isolator

Table 2 Load capabilities of test machine

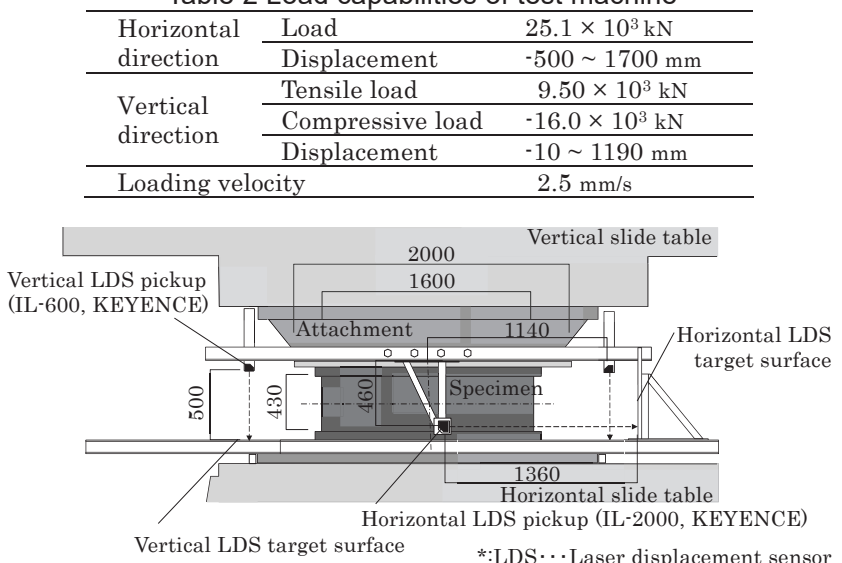

Fig. 4 Location of measurement device

LRB を静的単調載荷で破断可能となる載荷性能を設定して製作し ており， 1600 の実大スケールの LRB が余裕を持って破断できる 3)。試験体は水平スライドテーブルと鉛直スライドテーブルの間に ボルト固定され，それぞれのスライドテーブルに接続される水平 3 本，鉛直 4 本の油圧サーボ制御方式のジャッキにより加力される。 ジャッキの載荷速度は $2.5 \mathrm{~mm} / \mathrm{s}$ であり, 試験条件に即して荷重或い は変位で制御する。例えば，鉛直方向で荷重制御を行う場合には， 鉛直ジャッキ 1 本に目標荷重の $1 / 4$ の荷重が印加され, 残りのジャ ッキ 3 本がそのジャッキに追従するよう変位制御されることで, 試 験体のせん断変形に伴う転倒モーメントに対して鉛直スライドテー ブル面の水平レベルが保持される。試験装置の摺動抵抗はわずかで 
あったため, 摩擦力は補正しないこととした。破断時には, 急激な 荷重低下を検知し, その時の位置を保持寸る変位制御に切替えるこ とで, 急激な荷重変動に対する制御の安定性を確保した。

試験装置の制御のための荷重と変位の計測には, Fig. 3 に示寸各 ジャッキに設置したロードセルと磁歪式変位計を用いる。LRB の力 学特性評価にはジャッキのロードセルによる荷重と Fig. 4 亿示す水 平・鈆直スライドテーブル間を計測するレーザー変位計による相対 変位を用いた。レーザー変位計は水平方向に 2 点, 鉛直方向に 4 点 設置しており，各方向の平均值によって力学特性を評価した。

また, 試験体の固定状態は, 一部の固定ボルトのボルトゲージに よる軸ひずみや, 接触式変位計によるテーブル-フランジ間の変位を 計測した。ハードニング領域でフランジのすべりが発生したケース では, 水平変位からフランジのすべり量を引いて終局特性を評価し た。試験は温度管理されていない実験棟で行っており, 試験前に環 境温度と試験体のゴム表面温度を計測した。

\section{3. 試験結果}

\section{1. 基本特性の評価}

基本特性試験では, 面圧- $5 \mathrm{MPa}$ を印加した状態でせん断ひずみ振

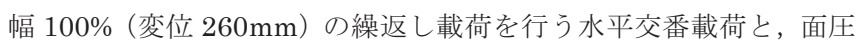
$-5 \mathrm{MPa}$ を中央值として $\pm 30 \%$ の変動面圧を与える鉛直交番載荷を行 った。それぞれ繰返し載荷は 4 ループ分行い，履歴が安定する 3 ル ープ目の履歴曲線から, JIS K 6410-220)に基づき基本特性として二 次剛性，降伏荷重特性値，圧縮剛性を算定した。

基本特性試験で得られた履歴曲線の一例を Fig. 5 に示す。Fig. 5 より水平方向と鉛直方向共に 3 ループ目で安定した履歴が描かれて いることが確認できる。

$\phi 1600$ 試験体の基本特性值を Fig. 6 に示す。二次剛性は温度, 降伏荷重特性值は温度や速度に影響を受けるため, 図中には温度と 速度の補正前後の基本特性值と設計值および試験時のゴム表面温度 を併記している。補正方法および設計值はゴムメーカによる評価式 22)に基づいており，(1)〜(3)に示寸補正係数を考慮することで, 二次 剛性が温度 $20^{\circ} \mathrm{C}$, 降伏荷重特性值が温度 $20^{\circ} \mathrm{C}$, 速度がせん断ひず み $100 \%$ で周波数 $0.33 \mathrm{~Hz}$ 相当に換算される。

$\alpha_{\mathrm{Kr}}=1.052-2.955 \times 10^{-3} \mathrm{t}+1.895 \times 10^{-5} \mathrm{t}^{2}$

$\alpha_{\mathrm{Qd}}=1.192-1.017 \times 10^{-2} \mathrm{t}+2.722 \times 10^{-5} \mathrm{t}^{2}$

$\beta_{\mathrm{Qd}}=1 /\left(0.0829 \times \log _{10}(\mathrm{f})+1.049\right)$

ここで, $\alpha_{\mathrm{Kr}}$ : 二次剛性の温度補正係数, $\alpha_{\mathrm{Od}}$ ：降伏荷重特性值の 温度補正係数, $\mathrm{t}$ : 温度 $\left[{ }^{\circ} \mathrm{C}\right], \beta_{\mathrm{Qd}}$ : 降伏荷重特性值の速度補正係数, f: 加振周波数 $[\mathrm{Hz}]$ を示す。

Fig. 6 の補正前の基本特性值のうち，b)に示す降伏荷重特性值は 表面温度と逆の傾向になっており, 降伏荷重特性值が温度に依存す ることが分かる。また, a),b)に示寸補正後の基本特性值は試験体に よらず概ね同等であり, 試験体は製造ばらつきが小さく, 均一に製 造されているといえる。補正後の基本特性值と設計值を比較すると, a)の二次剛性では概ね同等であるが，b)の補正後の降伏荷重特性值 と c)の圧縮剛性は設計值の $80 \%$ 程度になっている。このうち, b)の 降伏荷重特性值については, 基本特性試験の水平載荷速度 $2.5 \mathrm{~mm} / \mathrm{s}$ が一般的な載荷速度より低く, 補正式の適用範囲外となっている可 能性がある。c)の圧縮剛性が設計值より低くなったのは, 載荷条件

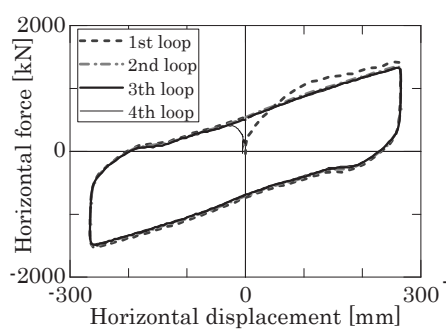

a) Horizontal direction

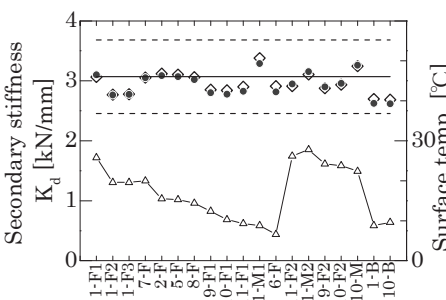

a) Secondary stiffness $K_{d}$

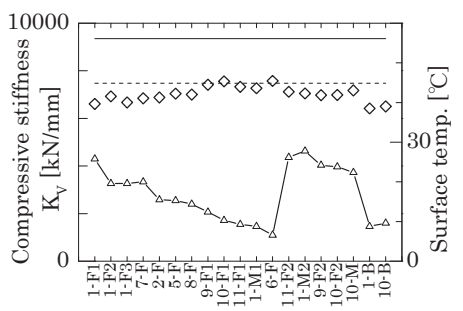

c) Compressive stiffness $K_{v}$ Fig. 6 Evaluation result of basic properties

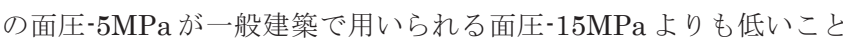
に起因していると考えられる。

\section{2. せん断破断試験の結果}

（1）試験の実施状況

せん断破断試験の載荷手順を面圧-5MPa せん断破断試験時の荷重 及び変位の計測結果と併せて Fig. 7 に示す。せん断破断試験では, まず過程(1)で目標面圧までの鉛直荷重を与え，面圧を保持した状態 で過程(2)のせん断ひずみ振幅 $100 \%$ 相当の水平交番 2 ループを行う。 その後, 過程(3)で水平変位を単調に増加させて破断させる。ここで, 水平交番載荷は, 線形限界の評価にあたって初期静止状態からのせ ん断変形開始時に，鉛プラグの塑性変形の影響により履歴曲線の直 線性が失われることを避けるための処置である。水平交番のせん断 ひずみ振幅 $100 \%$ は線形限界ひずみの半分以下の振幅であり，線形 限界以上の履歴曲線に繰返し載荷による影響はないと考えられる。

Fig. 7 の載荷結果のうち, d) の水平変位は $100 \mathrm{~s}$ 以降の水平交番や 1000s 以降の単調載荷において載荷目標の変位に即して変動してい た。c)の水平荷重から，1000s 以降で荷重勾配が増大しておりハー ドニングが発生していること，1500s 付近で荷重が急激に低下して LRB が破断したことが分かる。また，a）の鈶直荷重は，水平交番時 に水平変位の変動に伴って若干増減するものの，ハードニング開始 後も概水目標值に追従しており，終局状態における水平荷重変化に 対して鉛直荷重が保たれているといえる。以上より，せん断破断試 験において目標とした載荷が実現できていることが確認された。

（2）せん断破断試験における履歴曲線の評価 
すべてのせん断破断試験における水平方向の荷重-変位関係を Fig. 8, 破断点における応力およびひずみ值と試験体の表面温度を Table 3 の a) に示す。なお, 破断点は履歴曲線における最大応力発生時点 として評価した。せん断応力は水平荷重を鉛プラグを含むゴムの断 面で除して, せん断ひずみは水平変位をゴム総厚で除して, 軸応力 は鉛直荷重をゴム部の断面で除して, 軸ひずみは鉛直変位をゴム総 厚で除して算定した。

Fig. 8 の a)に示す実大試験体の各面圧の履歴曲線は, 線形範囲で 良く一致しており, 変位が約 $700 \mathrm{~mm}$ 以上（線形限界となるせん断 ひずみ $270 \%$ 相当）の，ハードニングから破断までの領域でも概ね 一致している。同一試験条件である面圧- $5 \mathrm{MPa}$ のせん断破断試験 3 ケース (1-F1〜1-F3) の履歴曲線および破断点はよく一致しており, 基本特性のばらつきが小さい LRB では終局特性のばらつきも小さ くなることが確認された。圧縮面圧下の破断時せん断ひずみは 439.4〜 465.9\%であり，一般的な積層ゴムにおいて目安とされる破 断時のせん断ひずみ $400 \%$ を回っていた。引張面圧下となる面圧

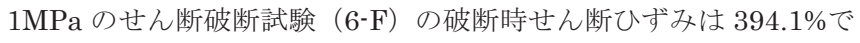
圧縮面圧下の結果よりやや小さかった。

Fig. 8 の)に示寸縮小試験体では, 最大面圧である-30MPa の履 歴曲線で負の勾配等の挙動をとっておらず，この面圧で座屈するこ
となく破断に至ったことが確認された。Fig. 8 の)に示すマルチプ ラグ試験体の 2 つの履歴曲線は, 線形範囲で概ね一致したが, 八ー ドニングから破断までの領域では $0^{\circ}$ 配置（1-M1）の剛性が高くな っていた。これに関して, Table 3 に示寸試験体表面温度を 0 配置 と $45^{\circ}$ 配置 (1-M2) とで比較すると, $0^{\circ}$ 配置が $20^{\circ} \mathrm{C}$ 程度低い温度条 件となっていることから，温度も影響しているものと考えられる。 また, Table 3 の)よりマルチプラグ試験体の破断時のせん断ひず みは $437.0 \%$ と $454.1 \%$ で実大試験体と同程度であった。Fig. 8 の) に示す製品 B 試験体の履歴曲線を実大試験体と比較すると, ハード ニング領域までの履歴はよく一致しており，破断時のせん断ひずみ は 412.1\%でやや小さかったが，400\%以上は確保されていた。

\section{3. 引張破断試験の結果}

（1）試験の実施状況

引張破断試験の載荷手順をオフセット $100 \%$ 引張破断試験の荷重 及び変位の計測結果と併せて Fig. 9 に示す。引張破断試験では，ま ず過程(1)で面圧- $5 \mathrm{MPa}$ 相当の鉛直荷重 $-9450 \mathrm{kN}$ を与え, 過程(2)で その鉛直荷重を保持して目標オフセットせん断ひずみ $100 \%$ 相当の 水平変位 $260 \mathrm{~mm}$ まで水平変形を与えた。その後，過程(3)で水平方

Table 3 Break test results a) shear break test

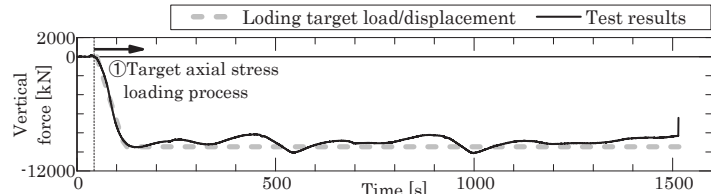

a) Vertical force

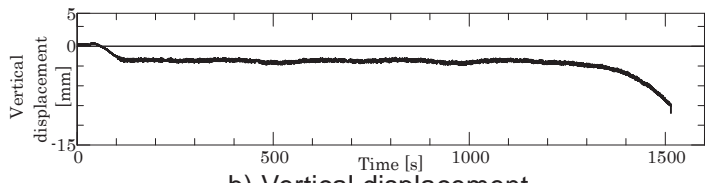

b) Vertical displacement

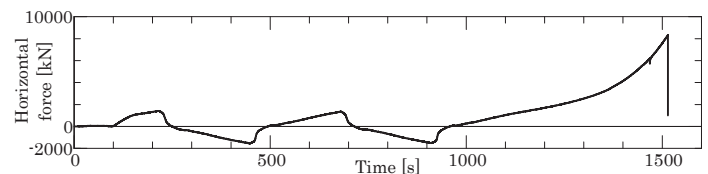

c) Horizontal force

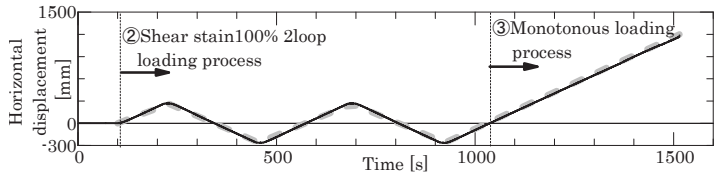

d) Horizontal displacement

Fig. 7 Time history of shear break test in axial stress $-5 \mathrm{MPa}(1-\mathrm{F} 1)$
Shear strain [\%]

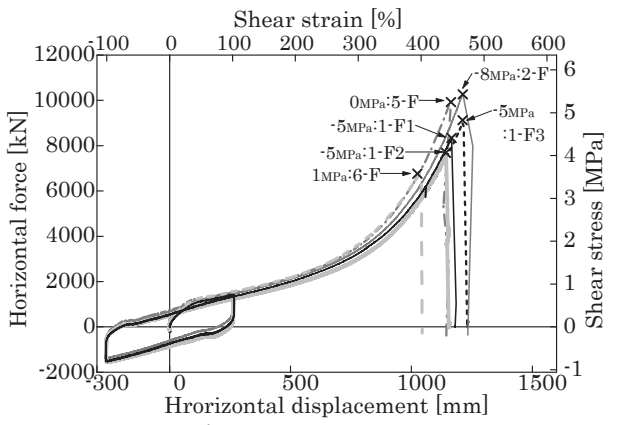

a) Full-scale type

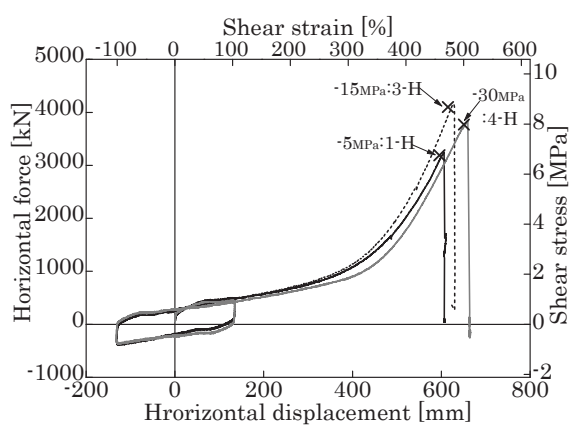

b) Half-scale type

\begin{tabular}{c|c|c|c|c|c|c|c|c|c}
\hline \multirow{2}{*}{ No } & \multirow{2}{*}{$\begin{array}{c}\text { Test } \\
\text { abbr. } \\
{ }^{* 1} 1\end{array}$} & \begin{tabular}{l} 
Test condition \\
\cline { 3 - 11 }
\end{tabular} & $\begin{array}{l}\text { Initial } \\
\text { axial } \\
\text { stress } \\
{[\mathrm{MPa}]}\end{array}$ & $\begin{array}{l}\text { Surface } \\
\text { temp. } \\
{\left[{ }^{\circ} \mathrm{C}\right]}\end{array}$ & $\begin{array}{l}\text { Shear } \\
\text { stress } \\
{[\mathrm{MPa}]}\end{array}$ & $\begin{array}{l}\text { Shear } \\
\text { strain } \\
{[\%]}\end{array}$ & $\begin{array}{l}\text { Axial } \\
\text { stress } \\
{[\mathrm{MPa}]}\end{array}$ & $\begin{array}{l}\text { Axial } \\
\text { strain } \\
{[\%]}\end{array}$ & Break surface \\
\hline 1 & $1-\mathrm{F} 1$ & -5 & 24.4 & 4.1 & 448.5 & -4.4 & -3.5 & 1 & Area \\
\hline 2 & $1-\mathrm{F} 2$ & -5 & 19.9 & 3.8 & 439.4 & -5.0 & -4.7 & 1 & Entire \\
\hline 3 & $1-\mathrm{F} 3$ & -5 & 20.1 & 4.5 & 465.9 & -5.0 & -4.4 & 1 & Entire \\
\hline 4 & $2-\mathrm{F}$ & -8 & 15.4 & 4.9 & 447.5 & -7.5 & -4.9 & 26 & Entire \\
\hline 5 & $1-\mathrm{H}$ & -5 & 8.0 & 6.3 & 458.2 & -3.0 & -2.9 & 25 & Part \\
\hline 9 & $3-\mathrm{H}$ & -15 & 8.3 & 8.2 & 473.0 & -13.4 & -8.1 & 12 & Part \\
\hline 7 & $4-\mathrm{H}$ & -30 & 10.8 & 7.5 & 500.5 & -27.1 & -18.9 & 6 & Part \\
\hline 8 & $5-\mathrm{F}$ & 0 & 19.1 & 5.1 & 466.4 & 0.3 & 0.5 & 6 & Entire \\
\hline 9 & $6-\mathrm{F}$ & 1 & 7.9 & 3.4 & 394.1 & 1.1 & 9.3 & 1 & Entire \\
\hline 10 & $1-\mathrm{M} 1$ & -5 & 8.0 & 4.6 & 437.0 & -4.8 & -3.6 & 1 & Part \\
\hline 11 & $1-\mathrm{M} 2$ & -5 & 28.8 & 3.5 & 454.1 & -4.9 & -4.0 & 1 & Part \\
\hline 12 & $1-\mathrm{B}$ & -5 & 10.4 & 3.3 & 412.1 & -5.1 & -2.1 & 26 & Part \\
\hline
\end{tabular}

b) Tensile break test

\begin{tabular}{|c|c|c|c|c|c|c|c|c|c|}
\hline \multirow[b]{2}{*}{ No } & \multirow[b]{2}{*}{$\begin{array}{l}\text { Test } \\
\text { abbr. } \\
{ }_{* 1}\end{array}$} & \multicolumn{2}{|c|}{ Test condition } & \multicolumn{4}{|c|}{ Breakage propriety value } & \multicolumn{2}{|c|}{ Break surface } \\
\hline & & $\begin{array}{c}\text { Offset } \\
\text { shear } \\
\text { strain } \\
{[\%]}\end{array}$ & $\begin{array}{l}\text { Surface } \\
\text { temp. } \\
{\left[{ }^{\circ} \mathrm{C}\right]}\end{array}$ & $\begin{array}{l}\text { Shear } \\
\text { stress } \\
{[\mathrm{MPa}]}\end{array}$ & $\begin{array}{c}\text { Shear } \\
\text { strain } \\
{[\%]}\end{array}$ & $\begin{array}{l}\text { Axial } \\
\text { stress } \\
\text { [MPa] }\end{array}$ & $\begin{array}{c}\text { Axial } \\
\text { strain } \\
\text { [\%] }\end{array}$ & layer & Area \\
\hline 13 & $7-\mathrm{F}$ & 0 & 19.8 & 0.0 & -0.5 & 3.4 & 291.6 & 26 & Entire \\
\hline 14 & $8-\mathrm{F}$ & 100 & 14.4 & 0.6 & 110.5 & 3.4 & 255.1 & 5 & Entire \\
\hline 15 & 9-F1 & 200 & 11.1 & 0.7 & 200.8 & 1.9 & 63.3 & 26 & Entire \\
\hline 16 & $9-\mathrm{F} 2$ & 200 & 25.0 & 0.8 & 207.6 & 2.1 & 141.1 & 1 & Entire \\
\hline 17 & 10-F1 & 300 & 10.3 & 1.5 & 298.2 & 1.8 & 22.3 & 1 & Entire \\
\hline 18 & $10-\mathrm{F} 2$ & 300 & 24.5 & 1.4 & 304.8 & 1.6 & 37.4 & 1 & Entire \\
\hline 19 & $11-\mathrm{F} 1$ & 400 & 8.6 & 2.9 & 387.8 & 2.1 & 12.4 & 2 & Entire \\
\hline 20 & $11-\mathrm{F} 2$ & 400 & 26.7 & 2.0 & 385.9 & 1. & 18.7 & 26 & Entire \\
\hline 21 & $10-\mathrm{M}$ & 300 & 22.9 & 1.4 & 305.9 & 1.7 & 52.4 & 1 & Part \\
\hline 22 & $10-\mathrm{B}$ & 300 & 10.2 & 1.4 & 304.7 & 1.7 & 41.8 & 26 & Entire \\
\hline
\end{tabular}

1:F: Full-scale type, H: Half-scale type, M: Multi-plug type, B: Product B type

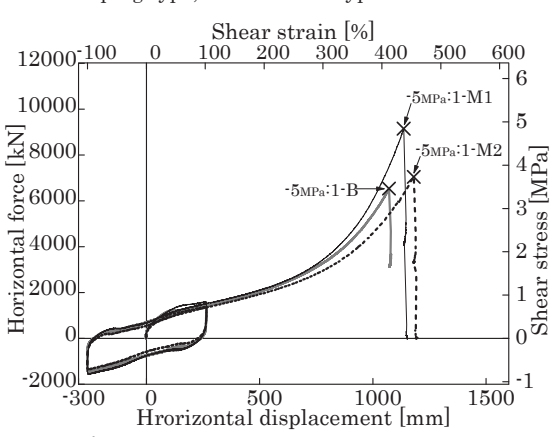

c) Multi-plug type and Product B type

Fig. 8 Horizontal hysteresis curve 
向のオフセットを保持した状態で鉛直変位を単調に増加させて破断 させた。

Fig. 9 に示す載荷結果のうち, a)の鉛直荷重から，100s で載荷目 標の鉛直荷重に到達したことが確認される。d)の水平変位は $200 \mathrm{~s}$ 付近で目標変位量 $260 \mathrm{~mm}$ に到達しておりb)の鉛直変位から, $200 \mathrm{~s}$ 以降で単調に増加し，480s 付近で破断していることが確認される。 a)の鉛直荷重では, 200s 以降の過程(3)の鉛直単調載荷によって荷重 方向が圧縮から引張に替わっていることと, 引張荷重領域に入った あとに荷重増分が小さくなりソフトニングを生じている様子が確認 された。この荷重変動下において鉛直変位は線形に増加しており正 常に載荷できたことが確認される。以上より, オフセット引張破断 試験で目標に沿った載荷が実施されたことが確認された。

(2) 引張破断試験における履歴曲線の評価

引張破断試験における鉛直方向の荷重-変位関係を Fig. 10, 破断 点の応力およびひずみ值と試験体の表面温度を Table 3 の b)に示す。 Fig. 10 の a),b)が実大試験体を対象とした試験の結果であり, a)に オフセット $0,100,200 \%$ の引張破断試験を, b) にオフセット $300,400 \%$ の引張破断試験を示す。ここで，a)のオフセット $100 \%$ の 引張破断試験（8-F） では, 鉛直変位 $42 \mathrm{~mm}$ までの載荷後に一端加 力を停止し，除荷した上で 2 回目の載荷で破断させた。また，b)の オフセット $400 \%$ の張破断試験 2 体目（11-F2）では，鉛直変位 $10 \mathrm{~mm}$ 付近で試験装置の故障により一時加力を中断した。そのため,

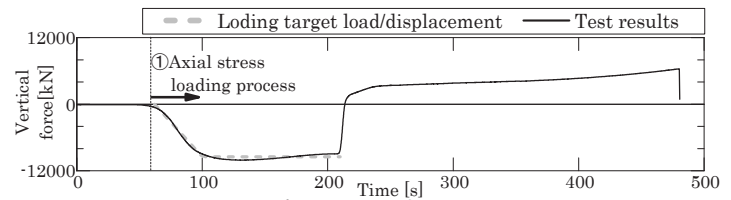

a) Vertical force

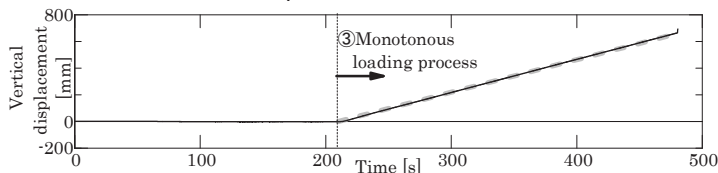

b) Vertical displacement

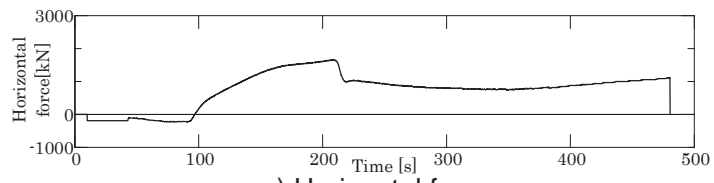

c) Horizontal force

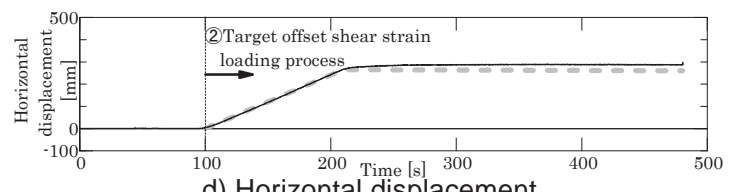

d) Horizontal displacement

Fig. 9 Time history of tensile break test in shear strain $100 \%$ (8-F)

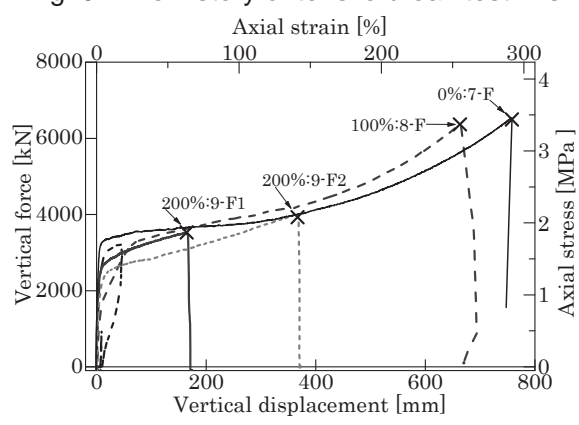

a) Full-scale type, offset $0-200 \%$

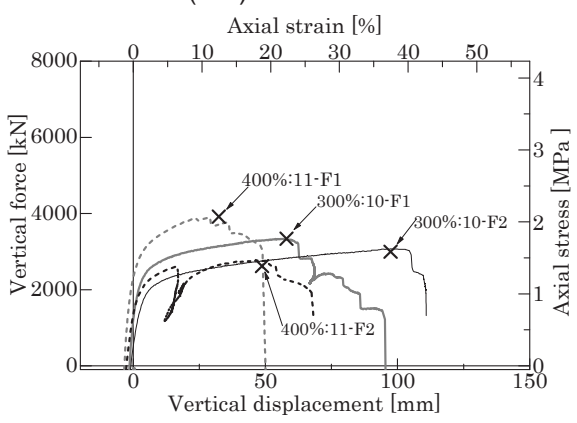

b) Full-scale type, offset $300-400 \%$ Fig. 10 Vertical hysteresis curve
これらの試験ケースでは履歴曲線が乱れている。

Fig. 10 の a),b)によれば，引張破断では鉛直荷重 $2000 \mathrm{kN}$ (軸応 力約 $1.0 \mathrm{MPa}$ ）を超えたあたりで岡性が低下寸るソフトニングを生 じている。a)のオフセット $0 \%, 100 \%$ の張破断試験（7-F, 8-F）で は軸ひずみ $150 \%$ 以上で剛性が増加するハードニングが発生した後 破断に至った。a),b)のオフセット $200 \%$ 以上の引張破断ではソフト ニング後に軸ひずみ $150 \%$ 以下で破断しており，オフセット量の増 大に伴い破断時の軸ひずみが低下寸る傾向が確認された。なお，後 述する破断時における変形形状においても，オフセット $200 \%$ オ境 として差異が確認されている。Table 3 の b)より，実大試験体の破 断時の軸応力は $1.4 \sim 3.4 \mathrm{MPa}$ であった。この数值は線形限界の目安 值 $1.0 \mathrm{MPa}^{19), 22)}$ に対して十分に余裕があるといえる。また，Fig. 10 の a),b)のオフセット $200,300,400 \%$ の同一載荷条件同士の履歴曲線 を比較すると, ソフトニングが始まる降伏点の応力が小さいケース で破断時の軸ひずみが大きくなっていることが確認された。さらに， 試験体の表面温度が高いケースで破断時の軸ひずみが大きくなる傾 向が認められる。このことは, 破断特性や線形限界が温度の影響を 受けている可能性を示唆している。

Fig. 10 の)に示すマルチプラグ試験体と製品 B 試験体の結果は, 実大試験体と同様に鉛直荷重 $2000 \mathrm{kN}$ を超えたあたりでソフトニン グを生じ，破断時の軸ひずみは $52.4 \%$ と $41.8 \%$ で Fig. 10 のb)に示 す実大試験体よりやや大きい程度であった。

\section{4. 線形限界の評価}

（1）線形限界ひずみ

せん断変形時の線形限界点は Fig. 11 の a)に示すように，ハード ニング開始点で定義される ${ }^{21)}$ 。本論文では, 線形限界を履歴曲線の せん断ひずみ 100 200\%間で最小二乗法により得られる直線の傾き を 1.2 倍した直線と, 履歴曲線との交点として求め, その交点のひ ずみ量を水平線形限界ひずみとして評価した。

算定結果として, 軸応力-線形限界ひずみ関係を Fig. 12 の a)に 示す。実大試験体の線形限界ひずみは $274 \sim 305 \%$ の範囲に分布し, 圧縮面圧下では面圧によらず概ね一定となっている。縮小試験体の 線形限界ひずみも実大試験体と同等であるが，面圧- $30 \mathrm{MPa}$ ではや や大きな值となっていた。マルチプラグ試験体では，Fig. 8 の)に 示した履歴曲線で確認したように，鉛プラグ配置方向によって差が あり，45配置の方が線形限界ひずみが大きかった。また，製品 $\mathrm{B}$ 試験体は実大試験体と同等であった。

（2）引張線形限界応力度

引張変形時の線形限界点は Fig. 11 のb)に示すソフトニングの開 


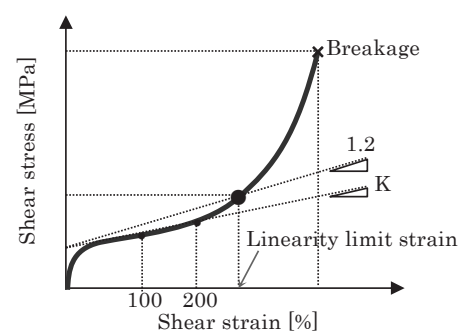

a) Horizontal direction

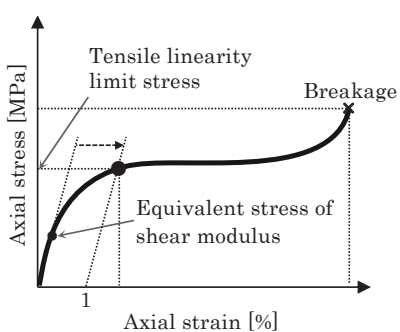

b) Vertical direction

Fig. 11 Evaluation method of linearity limit

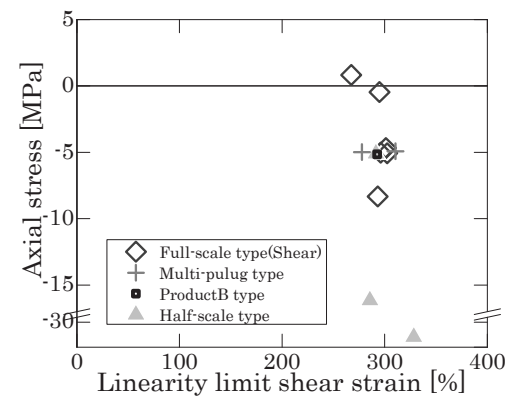

a) Horizontal direction

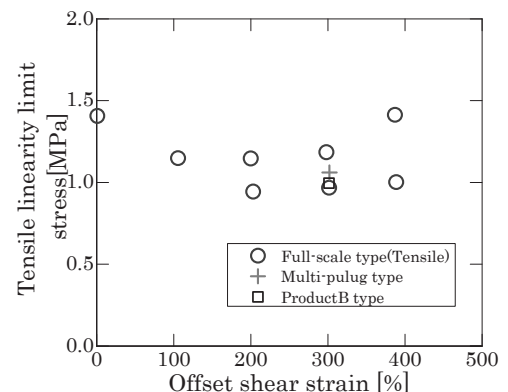

b) Vertical direction

Fig. 12 linearity limit

始点の応力で定義される。引張線形限界応力度は, 原点とゴム部材 のせん断弾性係数約 $0.4 \mathrm{~N} / \mathrm{mm}^{2}$ に相当する応力度を結ぶ直線を軸ひ ずみ方向へ $1 \%$ 分シフトした直線と履歴曲線との交点における応力 として評価する 20)。なお, オフセットを与えた引張破断試験ではせ ん断変形に伴って沈み込みを生じ, 引張載荷時の履歴曲線が原点を 通過しなくなるので，原点を通るように軸ひずみをシフトしてから 上記の算定方法を適用した。

算定結果として, 引張線形限界応力度-オフセットせん断ひずみ関 係を Fig. 12 の b) に示す。実大試験体の引張線形限界応力度は 0.93 1.48MPa であり, オフセット $200 \%$ で最小となった。引張線 形限界応力度はオフセット量によって傾向が変化しており, 水平方 向で変形が線形範囲となるオフセット $200 \%$ 以下では, 引張線形限 界応力度はオフセットの増大により減少する傾向を示しており, オ フセット $300 \%$ 以上の範囲では増加傾向に転じていた。この増加傾 向は水平方向のハードニング特性と対応するものと考えられ，才フ セットを与えた引張線形限界応力度が水平剛性の影響を含んだ特性 として評価されていること示唆している。また, Fig. 12 のb)によ れば, マルチプラグ試験体, 製品 $\mathrm{B}$ 試験体の引張線形限界応力度は 実大試験体の結果の範囲に収まっている。このことは, これら 3 種 類の LRB の引張方向の線形限界を同等と扱えることを示している。

\section{5. 破断特性の評価}

破断特性の評価結果として, 破断時の軸応力一せん断ひずみ関係, および軸ひずみ一せん断ひずみ関係を Fig. 13 に示す。

Fig. 13 のa)に示寸軸応力-せん断ひず夕関係から, 圧縮面圧下で は実大試験体と縮小試験体の破断時のせん断ひずみが面圧によらず 概ね一定となるように分布していることが確認された。さらに, 圧 縮面圧下では，マルチプラグ試験体の破断時のせん断ひずみは実大 試験体の結果と重なっており, 製品 B 試験体では実大試験体よりや や小さい結果となった。一方, 引張面圧下では, 実大試験体の破断 時の軸応力がオフセット量の増大に伴って減少している傾向が確認

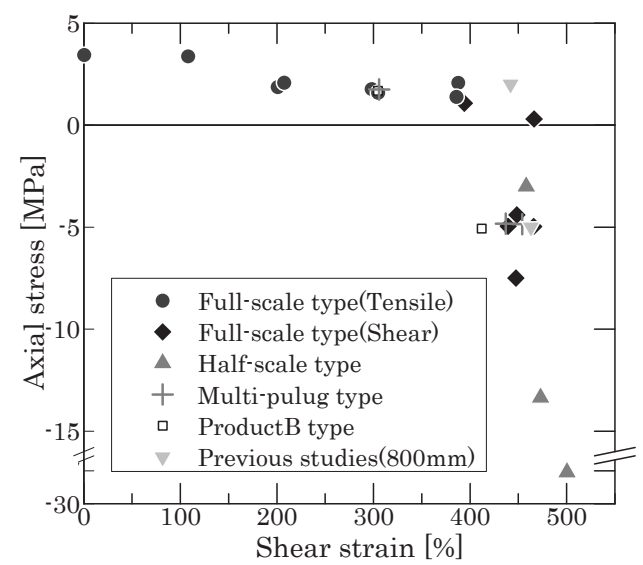

a) Axial stress-shear strain plane

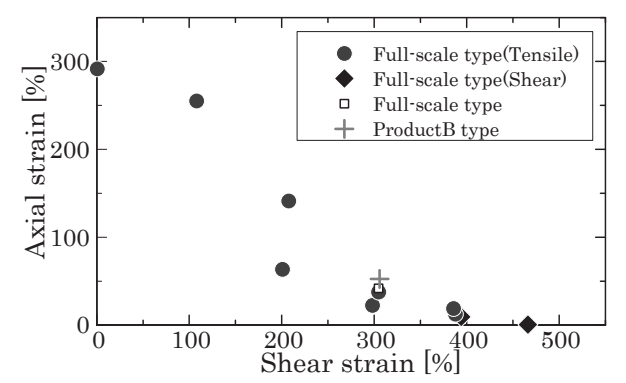

b) Axial strain-offset shear strain plane

Fig. 13 Breakage point

された。また, マルチプラグ試験体, 製品 $\mathrm{B}$ 試験体の破断時軸応力 が実大試験体の結果と同等であることが確認された。

Fig. 13 の)には, 本研究で先行試験 15) として実施した, 本論文 の試験体に近い形状の $\phi 800$ 試験体を対象とした静的単調載荷によ る破断試験の結果 2 点を併記している。この結果や本論文の縮小試 験体の結果との比較から, 本研究で取得した $\phi 1600$ の実大試験体の 破断特性が $\phi 800$ と大きく変わらないことが確認された。このこと は， $\phi 1600$ の LRB においても，1/2 スケールの試験体による破断 特性の代替評価 19)が適用可能であることを示唆している。

一方，Fig. 13 のb)に示寸破断時の軸ひずみ一せん断ひずみ関係上 の実大試験体の試験值の分布から，オフセット量の増大に伴い破断 時軸ひずみが減少するという従来から知られた傾向 12)が確認され た。詳細には, オフセット $200 \%$ を境としてオフセットに対する破 断時軸ひずみの減少傾向が変化しており, オフセット $200 \%$ 以上の 範囲で破断時の軸ひずみが小さくなる傾向が確認された。この傾向 変化については，次節にて詳述する。また，マルチプラグ試験体， 製品 B 試験体のオフセット $300 \%$ 引張破断試験の破断時軸ひずみは 実大試験体よりわずかに大きい程度で，同等性能であるといえる。

\section{6. 破断時における積層ゴムの変形形状}

(1) せん断破断試験

せん断破断時の試験体の変形形状の一例として, 面圧-5MPa せん 断破断試験の様子を Fig. 14 に示す。試験体には，変形状態を把握 しやすくするために積層ゴム部を高さ方向に 4 分割する白線のメッ シュを描いている。a)に載荷前の試験体を示す。b)は破断直前の変 形状態を示しており, 試験体下部に位置する水平スライドテーブル が左側に移動し, 積層ゴム部が一様にせん断変形している様子が確 認できる。破断開始点の位置は水平載荷方向中心軸の最下層のゴム 


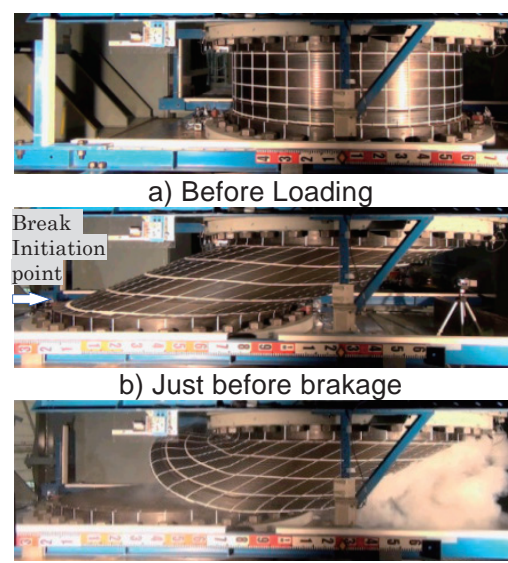

c) J ust after breakage

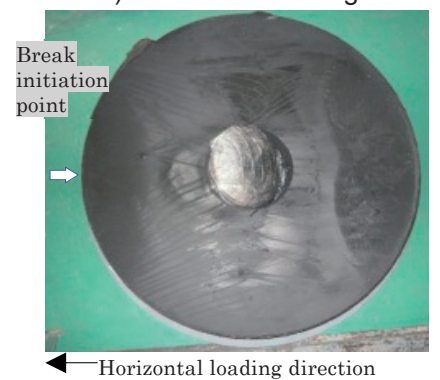

d) Upper break surface

Fig. 14 Deformation of LRB on shear break test in axial stress $-5 \mathrm{MPa}(1-\mathrm{F} 1)$

層の端部であった。破断時にはゴム層が破断開始点側から切り離さ れて, ゴム層が全面に渡って破断した後, 破断面上層の積層ゴム部 が右側に滑動して c)に示寸状態となった。c)中の試験体右側の白煙 は，試験後にゴムが焼けた匂いがしていたことから，破断後の滑動 時に破断面同士が擦れ合い, その摩擦熱によってゴムが気化するこ とで発生したものと考えられる。d)に上側の破断面を示す。破断面 は破断開始点を含めて全面がゴム部材であったことから，ゴムと中 間鋼板の接着不良等ではなくゴム材料の変形性能が限界に達したこ とで損傷（破断）に至ったことが確認された。

すべての試験条件について破断開始点の位置を Fig. 15, 詳細な破 断ゴム層の高さと，破断範囲を Table 3 の a) に示す。破断範囲とし て, Fig. 14 に示した破断がゴム層全面に進展しゴム層が分離する全 面破断と, 破断が全面に進展せず一部のゴム層が分離しない状態で 残る部分破断が確認された。いずれの試験ケースにおいても破断面 の破断開始点付近はゴム材料であったため, 損傷形態がゴムの破断 であることが確認された。

せん断破断では，ほとんどのケースで Fig. 14 のb)に示した破断 開始点位置と同じ部位である平面図上で水平載荷方向軸中心付近で かつ, 立断面図上でせん断変形が鋭角となる端部のゴム層で破断に 至っていた。例外は, 引張面圧下となる面圧 $1 \mathrm{MPa}$ のせん断破断試 験（6-F）で，このケースでは他のケースと逆向きの軸力が作用し ており, 破断開始点の位置は平面図上でゴム最上面と最下面が重複 する範囲（有効受圧範囲と称す）であることを確認した。

\section{(2) 引張破断試験}

引張破断時の試験体の変形形状として破断時の軸ひずみの差が大 きかったオフセット $100 \%$ と $200 \%$ の張破断試験の様子を Fig. 16, Fig. 17 に示寸。Fig. 16 はオフセット $200 \%$ の引張破断試験の変形

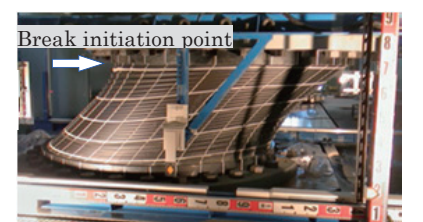

a) J ust before breakage

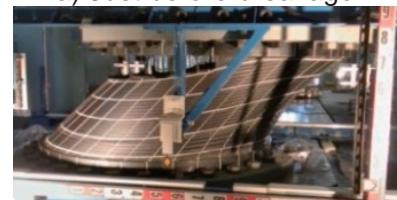

b) Breaking progress

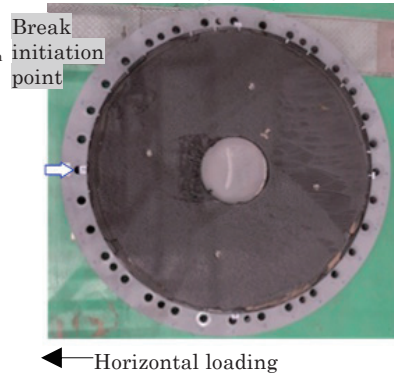

c) Upper break surface

Fig. 16 Deformation of $L R B$ on tensile break test in offset shear strain $200 \%$ (9-F 1$)$

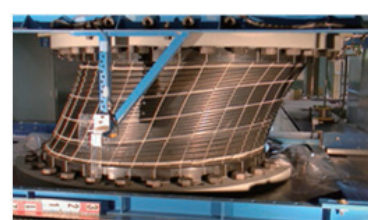

a) Axial strain $100 \%$

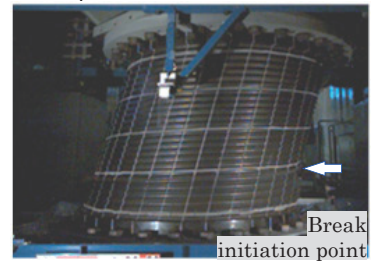

b) J ust before breakage

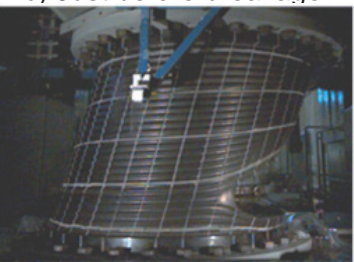

C) Breaking progress

Fig. 17 Deformation of LRB on tensile break test in offset shear strain $100 \%(8-F)$

形状であり，a)の破断直前には，積層ゴム部のメッシュが不均一に 変形して最上層のゴム層の左側端部が軸方向に大きく伸びており, そこから破断に至った。b)は破断の瞬間であり，せん断および引張 で積層ゴム部に蓄えられた復元力により図中左から右へと破断面が 離れながら破断が進展している様子が確認される。c)に示す上側の 破断面は，全面がゴム材料であり，破断開始点側でボイドが確認さ れ，逆側はせん断破断時の破断面と似た表面性状であった。才フセ ット引張試験では，せん断および引張の複合的な荷重による曲げモ 一メントが作用することで, 積層ゴム部が面外曲げ変形して, Fig. 16 の)でのメッシュが不均一となる変形の局所化を生じている。

一方, Fig. 17 に示寸オフセット $100 \%$ の張破断試験では，a)の オフセット後の軸ひずみ約 100\%時には, Fig. 16 の a)に示したオフ セット $200 \%$ 引張破断試験時と同様に端部ゴム層で軸方向の変形が 大きい不均一な変形形状となっている。しかし, その後のb)の破断 直前には, 各ゴム層が均等に伸長して破断に至っており, オフセッ ト $200 \%$ を境として破断時の変形形状も異なっていた。

Fig. 15, Table 3 のb)によれば，引張破断試験における破断開始 点位置は, 有効受圧範囲の上下端のゴム層近傍に分布している。こ の位置は積層ゴム部の面外曲げ変形によって軸変形しやすい位置で ある。なお， $7-\mathrm{F}$ は純引張破断試験であり，水平方向へのオフセッ 卜がないことで, 破断開始点位置が水平載荷軸上ではなかったと考 えられる。また, 前項(1)で述べたせん断破断試験のうち引張面圧下 で試験した 6-F も有効受圧範囲の端部ゴム層が破断開始点となって おり，軸力の作用方向によって破断開始点が特徴付けられる。

3.5節の Fig. 13 のb)で確認されたオフセット量の増加に伴う破断 時軸ひずみの減少傾向は, せん断力および引張軸力によって積層ゴ ム部に曲げモーメントが作用し，面外曲げ変形を生じることで破断 開始点位置の軸変形が増大寸ることで発生していると考えられる。 さらに, 鉛プラグ孔が引張軸力を伝達しないことが, オフセット量 
の増大に伴う端部ゴム層付近での軸方向への変形集中を助長してい ると考えられる。

\section{4. 破断限界および線形限界の検討}

\section{1. 設定方法}

原子力発電所施設の残余のリスク評価で参照される構造要素の現 実的耐力 23)として, 試験結果に基づいて積層ゴムの健全性評価にお ける線形限界と破断限界を設定した。

線形限界と破断限界は, 免震構造設計技術指針 17)の考え方を踏襲 して, 実大試験体の試験結果から, 軸応力-せん断ひずみ関係上で設 定した。さらに, 引張破断では線形限界以降の破断までの領域で軸 応力と比較して軸ひずみの変化が大きいため, 軸ひずみ一せん断ひず み関係上での破断限界を検討した。また, 試験結果にはばらつきが 含まれるため, 確率統計量で表現することとし, 以下の(4) (6)式に よる回帰式とその標準偏差を求めた。

軸応力-せん断ひずみ関係 ;

$$
\begin{array}{lll}
\mathrm{Y}=\mathrm{a} & (\sigma \leqq \mathrm{d}, \text { 圧縮面圧 }) & \cdots \cdots(4) \\
\sigma=\mathrm{by}+\mathrm{c} & (\sigma>\mathrm{d}, \text { 引張面圧 }) & \cdots \cdots(5)
\end{array}
$$

軸ひずみーせん断ひずみ関係；

$$
\frac{\mathrm{Y}}{\mathrm{a}}+\frac{\varepsilon}{\mathrm{e}}=1 \quad(\varepsilon \geqq 0)
$$

ここで, $\mathrm{Y}$ ：せん断ひずみ, $\sigma$ ：軸応力, $\varepsilon$ ：軸ひずみ, $\mathrm{a} \sim \mathrm{e}$ ：回帰係 数であり, a,c,e は確率変数, b,d は確定変数とした。

まず，軸応力-せん断ひずみ関係の回帰係数の推定では，前節で考 察した破断状態がせん断破断と引張破断の 2 種類に区分されること を考慮して, 圧縮面圧と引張面圧で分けた 2 直線を設定した。圧縮 面圧下では実大試験体のせん断破断試験のデータ 5 点から(4)式に よりせん断ひずみ一定の直線, 引張面圧下では実大試験体の引張破 断試験のデータ 8 点から(5)式によりせん断ひずみを変数として軸 応力を示寸直線を定義した。(4)式と(5)式の境界となる軸応力が係数 d となる。線形限界については圧縮面圧下で破断限界と同じデータ 5 点, 引張面圧下ではオフセット $300 \%$ 以下のデータ 6 点から, 破 断限界と同じ式によって求めた。

一方，引張破断試験時の軸ひずみ一せん断ひずみ関係では，(6)式 による直線を設定した。(6)式では軸応力-せん断ひずみ関係上の破 断限界との連続性を考慮して, 軸ひずみ $0 \%$ にけるせん断ひずみ に(4)式と同じ回帰係数 a を用いた。また採用する試験データは, 実 大試験体のオフセット $300 \%$ 以上の張破断試験のデータ 4 点とし た。これは，試験で確認されたオフセット $200 \%$ を境とした破断時 軸ひずみの減少傾向変化と, 地震応答解析 ${ }^{13}$ )により評価上重要であ ることが確認されたオフセット量の大きい領域での引張面圧の評価 精度を良くすることに配慮して設定したものである。

\section{2. 評価結果}

(1)軸応力-せん断ひずみ関係

軸応力-せん断ひずみ関係上の線形限界および破断限界の評価結 果を Fig. 18, Table 4 に示す。Fig. 18 中には，実大試験体の結果 と比較するために縮小試験体による破断点を併せて示している。

Fig. 18 より,いずれの試験結果も回帰式の標準偏差に概ね包絡さ れていることから，(4),(5)式による回帰式は試験結果を適切に表現

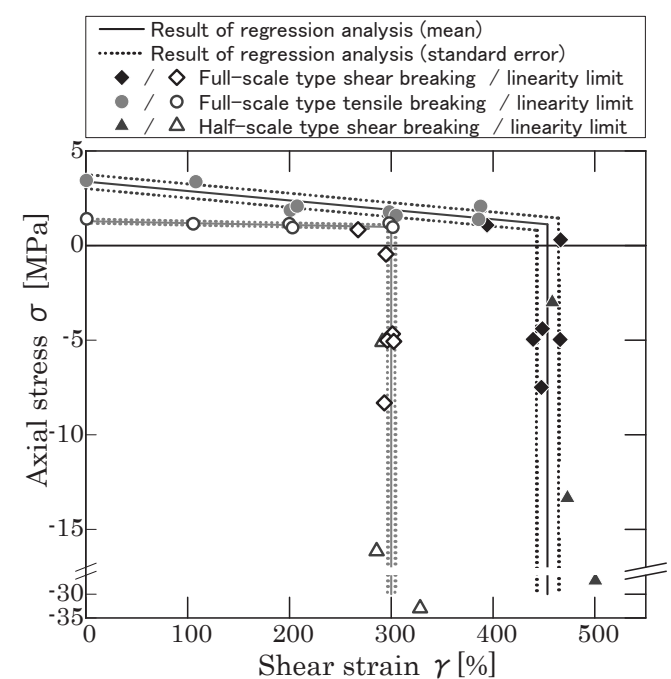

Fig. 18 Break limit and linearity limit in axial stress - shear strain plane

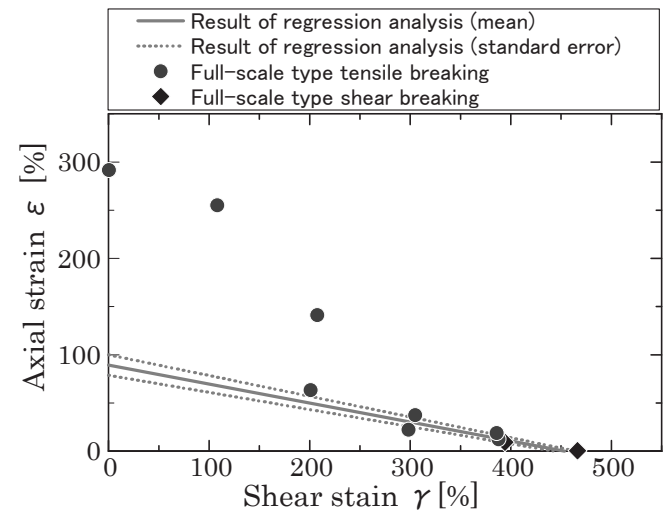

Fig. 19 Break limit in axial strain - shear strain plane

Table 4 Result on regression coefficients

\begin{tabular}{c|ccccc}
\hline \multirow{2}{*}{ Criteria } & \multicolumn{5}{|c}{ Regression coefficient } \\
\cline { 2 - 6 } & $\mathrm{a}[\%]$ & $\mathrm{b}[\mathrm{MPa} / \%]$ & $\mathrm{c}[\mathrm{MPa}]$ & $\mathrm{d}[\mathrm{MPa}]$ & $\mathrm{e}[\%]$ \\
\hline $\begin{array}{c}\text { Linearity } \\
\text { limit }\end{array}$ & $\begin{array}{l}297.6 \\
(3.6)^{*}\end{array}$ & $-1.02 \mathrm{E}-3$ & $\begin{array}{c}1.32 \\
(0.109)\end{array}$ & 1.02 & - \\
\hline $\begin{array}{c}\text { Ultimate } \\
\text { limit }\end{array}$ & $\begin{array}{l}453.5 \\
(10.8)\end{array}$ & $-4.97 \mathrm{E}-03$ & $\begin{array}{c}3.37 \\
(0.374)\end{array}$ & 1.12 & $\begin{array}{c}\text { (1.9. } \\
(10.6)\end{array}$ \\
\hline
\end{tabular}

*1: Figures in parentheses are indicate the standard deviation.

しているといえる。縮小試験体による高面圧下のせん断破断試験の 結果は回帰式の標準偏差より大きいひずみ側に位置しており，この 領域では回帰式が保守的な評価結果となっている。また，係数 $\mathrm{d}$ は 線形限界で $1.02 \mathrm{MPa}$ であり, 一般的な積層ゴムの引張線形限界応 力度の $1.0 \mathrm{MPa}^{19), 22)}$ と同等であり，既往の知見と整合している。

(2)軸ひずみ-せん断ひずみ関係

軸ひずみーせん断ひずみ関係上の破断限界の評価結果を Fig. 19,

Table 4 に示す。Fig. 19 よりオフセット 300\%以上の試験結果は回 帰式の標準偏差範囲にあることが分かる。一方，オフセット $200 \%$ 以下では，回帰線は試験結果の軸ひずみを大きく下回っている。た だし，地震動条件や建屋応答においてオフセット $200 \%$ 以下の範囲 で(6)式から求まる軸ひずみを超える鉛直挙動をとる可能性は極め て低いと考えられるため, 評価上は問題にならないと思われる。

なお，オフセット $200 \%$ を境とした破断時軸ひずみの傾向変化に 関しては，解析等による分析を踏まえて破断限界の評価へ反映して いくことが期待される。 


\section{5.まとめ}

本論文では, 免震構造を適用した原子力発電施設の残余のリスク 評価で必要となる免震要素単体の終局特性を把握することを目的と して, 原子力発電施設向けに設計した $\phi 1600$ の鉛プラグ入り積層ゴ ムを対象に実機スケールの試験体を用い，積層ゴム部の損傷に着目 した静的単調載荷による破断試験を実施した。試験結果に基づいて 破断事象を詳細に分析するとともに, 積層ゴムの健全性評価におけ る線形限界と破断限界を設定した。得られた知見を以下に示す。

（1） ф1600 の鉛プラグ入り積層ゴムの破断限界として, 圧縮面圧下 におけるせん断破断試験での破断時せん断ひずみは 439.4〜 $466.4 \%$ で一般的な積層ゴムで目安とされる $400 \%$ 以上を確保でき ること, 引張破断試験での破断時軸応力は $1.4 \sim 3.4 \mathrm{MPa}$ となるこ とを確認した。これらの結果は, 既往試験や本研究での $\phi 800$ の 試験結果と整合しており， $\phi 1600$ までの積層ゴムで，1/2 スケー ルによる代替試験の結果が準用できることを示唆している。

（2）実大試験体のオフセットを与えた引張破断試験では，従来から 知られているオフセット量の増大に伴う破断時軸ひずみの減少傾 向が確認され, 特にオフセット $200 \%$ 上小範囲で軸ひずみの減 少量が増加していた。引張破断時の積層ゴムの変形状態から, オ フセットに伴う破断時軸ひずみの減少傾向は, せん断力および引 張軸力によって積層ゴム部に曲げモーメントが作用し, 面外曲げ 変形を生じることで破断開始点位置の軸変形が促進されることで 発生していることを確認した。

（3）鉛プラグを分散して配置したマルチプラグ試験体および実大 試験体と同一仕様で製造方法が異なる製品 B試験体についての面 圧-5MPa のせん断破断試験とオフセットせん断ひずみ $300 \%$ の引 張破断試験の結果から, これらが実大試験体と同等の線形限界, 破断性能を有していることを確認した。

（4）積層ゴムの健全性評価に用いる線形限界および破断限界を試験 データに基づいて設定した。破断限界は, 軸応力-せん断ひずみ関 係上で圧縮面圧と引張面圧の 2 つ領域に分けて試験結果の回帰 式として求めた。実規模試験に基づく線形限界および破断限界を 残余のリスク評価に反映することで, より信頼性の高い評価が可 能となる。

上記(2)で述べた引張破断におけるオフセット量の増大に伴う破 断時軸ひずみの減少傾向の変化に関して, そのメカニズム分析のた めの FEM 解析を実施している。また, 破断後の積層ゴムの残存性 能評価に関寸る試験や, 破断後の積層ゴムから切り出したゴムの材 料試験等も実施している。これらの研究結果については稿を改めて 報告する。

\section{謝辞}

本論文は経済産業省補助事業「発電用原子炉等安全対策高度化技 術開発」の一環として実施された, 日本原子力発電株式会社, 北海道 電力株式会社, 東北電力株式会社, 東京電力株式会社, 中部電力株式会 社, 北陸電力株式会社, 関西電力株式会社, 中国電力株式会社, 四国電 力株式会社, 九州電力株式会社, 電源開発株式会社, 株式会社東芝, 日 立 $\mathrm{GE}$ ニュークリア・エナジー株式会社, 三菱重工業株式会社, 財団 法人エネルギー総合工学研究所が参加する電力共通研究「免震シス
テムの評価手法開発」における研究内容の一部をまとめたものであ る。首都大学東京 西川孝夫名誉教授, 東京大学 藤田隆史名誉教授, 東京大学 久保哲夫名誉教授, 東京大学 笠原直人教授, 電力中央研 究所 矢花修一博士にご指導頂いた。ここに記して謝意を表す。

\section{参考文献}

1）小杉慎司，平田和太ほか：次世代軽水炉の免震技術の開発 その 17 , 日本 建築学会大会学術講演梗概集, 構造 II, pp.1257-1258, 2012.9.

2）栗原圭祐，金澤健司ほか：原子力施設の免震技術の開発 その $4 \sim 8$, その $13 \sim 16$, その 18 , その $25 \sim 27$, 日本建築学会大会学術講演梗概集, 構造 II, pp.1135-1144, 2014.9, pp.1143-1150, 2015.9, pp.1153-1154, 2015.9, pp.1343-1348, 2016.9 .

3) S. Kosugi, et al.: Development of an Evaluation Method for Seismic Isolation Systems of Nuclear Power Facilities, Part 7-9, Proc. of ASME 2014PVP, PVP2014-29009, -29006, -29001, 2014.7

4) T. Imaoka, et al: Development of Evaluation Method for Seismic Isolation Systems of Nuclear Power Facilities, -Break Test of Full Scale Lead Rubber Bearings for Nuclear Facilities, Part 2-3, 4," Trans. of the 21th SMiRT, Manchester, 2015, 8 .

5）例えば，平田和太，矢花修一ほか：高速増殖炉免震設計法に関寸る研究, （一財） 電力中央研究所総合報告 U34, 1998.10.

6）原子力発電所免震構造技術指針（JEAG4614-2000），（一財）日本電気 協会, 2000.7 .

7）原子力安全委員会：発電用原子炉施設に関する耐震設計審查指針の改定, 2006.9.19

8）山本知史，古川茂ほか：次世代軽水炉の免震技術の開発その 1 , 日本建築 学会大会学術講演梗概集, B-2, pp.1131-1132, 2010.9 .

9) T.Kubo, et al.: A Seismic Design of Nuclear Reactor Building Structures Applying Seismic Isolation system in a High Seismicity Region -A Feasibility Case Study in Japan-, Nuclear Engineering and Technology, vol.46 Issue5,pp.581-594, 2014.10.

10）松田泰治，岡陽一ほか: FBR 免震システム確証試験 大型免震要素試験そ の 2, 日本建築学会大会学術講演梗概集, B 構造 I, pp757-758, 1990.10.

11) K. Ishida, et al.: Failure tests of laminated rubber bearings, 11th SMiRT K25/5, pp.241-246, 1991.

12）高山峯夫：免震構造用天然ゴム径積層ゴムアイソレータの限界性能，日 本建築学会技術報告集，第 1 号, pp160-165, 1995.2 .

13）瓜生満，中山一彦ほか：高面圧下における積層ゴムアイソレータの実大 実験 その 5, 日本建築学会大会学術講演梗概集, B-2 構造 II, pp.705-706, 1996.9.

14）松村佳孝，西川一郎ほか：大サイズ天然ゴム系積層ゴムアイソレータの 引張特性, 日本建築学会技術報告集, 第 12 号, pp.53-56, 2001.1.

15）神保雅一ほか：次世代軽水炉の免震技術の開発 その 7 , 日本建築学会大 会学術講演梗概集, B-2, 構造 II, p.p.1143-1144, 2010.9 .

16）金澤健司，矢花修一ほか：積層ゴム破断時における免震構造システムの 地震応答, 日本建築学会構造系論文集,第 77 巻 第 679 号, pp.1383-1392, 2012.9 .

17）原子力発電所免震構造技術指針（JEAG4614-2013），（一財）日本電気 協会, 2013.5 .

18) H.Asano, et al.: Development of Evaluation Method for Seismic Isolation Systems of Nuclear Power Facilities, Part 10 Proc. of ASME 2014PVP, PVP2014-29040, 2014.7

19）免震部材標準品リスト 2009, 日本免震構造協会, p323, 2009.10.30.

20）建築免震用積層ゴム支承-第 2 部：試験方法 JIS K 6410-2:2011，日本規 格協会, 2011.8.22.

21）原子力発電所免震構造技術指針（JEAG4614-2013），（一財）日本電気 協会，参 8-16, 2013.5.

22）株式会社ブリヂストン: 鉛プラグ挿入型積層ゴム支承 技術資料（認定番 号：MVBR-0447），2013.2.

23）原子力学会：原子力発電所の地震を起因とした確率論的安全評価実施基 準 2007，2007.9. 


\title{
ULTIMATE PROPERTIES OF LARGE-SCALE LEAD RUBBER BEARING \\ USING FULL-SCALE BREAK TEST
}

\author{
Shinji KOSUGI ${ }^{* 1}$, Tetsuo IMAOKA ${ }^{* 2}$, Kenji KANAZAWA*3, \\ Takafumi HIRAKI*4, Seiji NAGATA*5 , Takashi NAKAYAMA*6, \\ Kunihiko SATO*7, Masakazu JIMBO ${ }^{* 8}$ and Yoshito UMEKI*9 \\ ${ }^{* 1}$ Staff Engineer, Hitachi-GE Nuclear Energy, Ltd., M.Eng. \\ ${ }^{* 2}$ Senior Engineer, Hitachi-GE Nuclear Energy, Ltd. \\ *3 Senior Research Engineer, Central Research Institute of Electric Power Industry, Dr.Eng. \\ ${ }^{* 4}$ Research Engineer, Central Research Institute of Electric Power Industry, M.Eng. \\ ${ }^{* 5}$ Research Engineer, Central Research Institute of Electric Power Industry, Dr.Eng. \\ ${ }^{* 6}$ Senior Manager, Kajima Corporation, M.Eng. \\ ${ }^{*}$ Deputy Chief Engineer, Mitsubishi Heavy Industries, Ltd. \\ ${ }^{* 8}$ Chief Specialist, Toshiba Corporation, M.Eng. \\ ${ }^{* 9}$ Senior Manager, Chubu Electric Power Co., Inc., M.Eng.
}

Application of a seismic base-isolation system to nuclear power plants (NPPs) facilities using a 1600-mm diameter lead rubber bearings (LRBs) has been considered for the purpose of enhancing seismic safety. Obtaining the mechanical properties of the LRBs is important, especially over the design limit, so that the seismic safety margin of the seismic base-isolated structure can be estimated against seismic events beyond design basis. Recent studies reveal that the scaled effect appears on the ultimate properties of the rubber bearings at the axial tensile break. However, the ultimate properties of such a large scale LRBs have not been confirmed. Therefore, in this study, to evaluate the realistic mechanical properties of the full-scale LRBs design for nuclear facilities, break tests are conducted on real-size LRBs in order to avoid the difficulties considering size effect. This paper presents twenty-two break test results of the full-scale and half-scale LRBs, mainly focusing on two points: one is the mechanical properties of the 1600-mm diameter LRBs such as its basic properties, linearity limit properties, and ultimate properties and the other is the statistical model of the linearity limit and the break limit of the seismic isolator on the basis of the break test, which is applied to investigate the residual risk of seismically isolated NPPs.

The break limit states of the full-scale LRBs are well-evaluated as expected; i.e., the breaking shear strains under the compressive stress exceed the commercial reference value of $400 \%$. These results are consistent with the test results of the 800-mm diameter LRBs in this study and the previous test, it was suggest that the ultimate properties of the LRBs up to $1600-\mathrm{mm}$ in diameter can be evaluated by the alternative $1 / 2$ scale test.

As a result from the break test at various loading conditions for the full-scale LRBs, the breaking shear strain in the shear break under the axial compression was found to be substantially constant regardless of the axial stress value. On the tensile break test, decreasing trend of the breaking axial strain with the horizontal offset amount increased has been confirmed. In detail, the decreasing trend of the breaking axial strain changes at the offset shear strain of $200 \%$, the breaking axial strain of the large offset range is relatively smaller. From the deformed state of the LRBs on the tensile breaking, it was confirmed that axial deformation of the vicinity of the break initiation point located the upper and lower ends of the rubber layer is promoted by a bending moment caused by increasing horizontal offset amount and the axial tensile loading.

A statistical model of the linearity limit and the break limit of the seismic isolator were evaluated on the basis of the break test of the full-scale LRBs. In accordance with the concept of the Japanese design guidelines for the seismically isolated NPPs, the regression formulas of the break limit were defined in the axial stress-shear strain plane, or the tensile strain-shear strain plane. Further, the regression formulas of the linearity limit were defined in the axial stress-shear strain plane. By using of these statistical model of limit state of the LRBs, a residual risk for seismic base-isolated NPPs against seismic events beyond design basis can be investigate more accurately. 